\title{
Exenatide twice daily versus insulin glargine for the treatment of type 2 diabetes in Poland - subgroup data from a randomised multinational trial GWAA
}

\author{
Porównanie skuteczności eksenatydu i glarginy w leczeniu cukrzycy typu 2 \\ - obserwacje polskiej grupy badania klinicznego GWAA

\section{Beata Matyjaszek-Matuszek ${ }^{1}$, Monika Lenart-Lipińska, ${ }^{1,2}$, Dorota Rogalska ${ }^{3}$, Andrzej Nowakowski ${ }^{1}$, GWAA Polish Study Group}

${ }^{1}$ Chair and Department of Endocrinology, Medical University of Lublin, Poland

${ }^{2}$ Chair and Department of Laboratory Diagnostics, Medical University of Lublin, Poland

${ }^{3}$ Eli Lilly Poland, Medical Department, Warsaw, Poland

\begin{abstract}
Introduction: We explored the safety and efficacy of exenatide BID $v$. insulin glargine in a subgroup of Polish patients with type 2 diabetes sub-optimally controlled with metformin plus a sulfonylurea, participating in a 26-week randomised, controlled open-label trial. Material and methods: In Poland, 80 patients $\left(\mathrm{HbA}_{1 \mathrm{c}} 7-10 \%\right.$, BMI $\left.25-45 \mathrm{~kg} / \mathrm{m}^{2}\right)$ were randomised to exenatide $10 \mu \mathrm{g}$ BID $(\mathrm{n}=40)$ or insulin glargine once daily $(n=40)$. We present exploratory analyses on $\mathrm{HbA}_{1 c^{\prime}}$ glucose profiles, body weight, hypoglycaemia and adverse events (AEs).

Results: Mean (SD) baseline HbA1c was 7.9\% (0.86) for exenatide and 7.8\% (1.02) for insulin glargine. At Week 26, LS mean (SEM) HbA1c decreased in both groups (exenatide $-0.72 \%$ [0.12]; glargine $-0.64 \%$ [0.12]), as did fasting glucose. Postprandial glucose excursions after breakfast and dinner were smaller in patients treated with exenatide. LS mean (SEM) body weight decreased by $-1.9(0.48) \mathrm{kg}$ with exenatide and increased by $1.6(0.48) \mathrm{kg}$ with glargine (group difference [95\% CI]: $-3.5 \mathrm{~kg}$ [-4.9 to -2.2$]$ ). Hypoglycaemia was low in both groups; nocturnal hypoglycaemia was reported for three $v$. seven patients (three $v .24$ episodes) in the exenatide and glargine groups, respectively. Adverse events were more common with exenatide (nausea $\mathrm{n}=22 v \cdot \mathrm{n}=1$, vomiting $\mathrm{n}=5 v \cdot \mathrm{n}=0$, headache $\mathrm{n}=8 v \cdot \mathrm{n}=2$ ). Conclusion: This exploratory analysis confirms that findings from the global study apply to patients treated with exenatide BID and

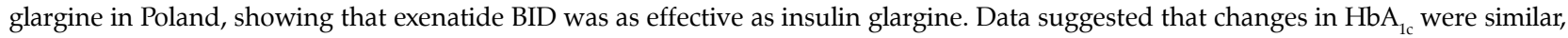
with fasting glucose changes greater in the glargine group and postprandial changes greater in the exenatide BID group. Exenatide BID was associated with weight reduction, less nocturnal hypoglycaemia, but more gastrointestinal events compared to glargine. (Endokrynol Pol 2013; 64 (5): 375-382)
\end{abstract}

Key words: type 2 diabetes mellitus, GLP-1 agonist, exenatide, insulin glargine

\section{Streszczenie}

Wstęp: Ocena bezpieczeństwa i efektów leczenia analogiem GLP-1 (eksenatyd) i długodziałajacym analogiem insuliny (glargina) pacjentów z cukrzycą typu 2, nieskutecznie leczonych doustną terapia skojarzoną, biorących udział w polskiej grupie 26-tygodniowego, wieloośrodkowego, otwartego, randomizowanego badania klinicznego GWAA.

Materiał i metody: 80 pacjentów z cukrzycą typu 2 skojarzoną z otyłością (BMI $\left.25-45 \mathrm{~kg} / \mathrm{m}^{2}\right)$, nieskutecznie $\left(7 \%<\mathrm{HbA}_{1 \mathrm{c}}<10 \%\right)$ leczonych doustną terapią skojarzoną (metformina + pochodna sulfonylomocznika) zostało zrandomizowanych do dwóch grup leczenia interwencyjnego. Pierwsza otrzymywała eksenatyd $20 \mu \mathrm{g} /$ dobę, a druga glarginę w jednej dawce na dobę. Analizie porównawczej poddano masę ciała, $\mathrm{BMI}, \mathrm{HbA}_{1 \mathrm{c}^{\prime}}$ dobowy profil glikemii i działania niepożądane.

Wyniki: Średnie stężenie $\mathrm{HbA}_{1 \mathrm{c}}$ było $7,9 \%(0,86)$ i 7,8\% $(1,02)$ w odpowiednich grupach, W 26 tygodniu leczenia uzyskano redukcję $\mathrm{HbA}_{1 \mathrm{c}}$ w obu grupach (eksenatyd -0,72\% [0,12]; glargina -0,64\% [0,12]). Poposiłkowa glikemia, po śniadaniu i kolacji, była niższa u pacjentów leczonych eksenatydem. Masa ciała w tej grupie uległa redukcji 1,9 $(0,48) \mathrm{kg}$, natomiast wzrosła 1,6 $(0,48) \mathrm{kg}$ u pacjentów leczonych insuliną (różnica: $-3,5 \mathrm{~kg}$ [95\% CI -4,9; -2,2]). Nocne hipoglikemie zostały zgłoszone przez 3 pacjentów w porównaniu do 7 (3 v. 24 epizody) odpowiednio w grupie leczonej eksenatydem i glarginą. Objawy uboczne występowały częściej w grupie leczonej eksenatydem (nudności $\mathrm{n}=22 v \cdot \mathrm{n}=1$, wymioty $\mathrm{n}=5 \mathrm{v}$. 0 , bóle głowy $\mathrm{n}=8 v \cdot \mathrm{n}=2$ ) w porównaniu $\mathrm{z}$ grupą leczoną glarginą.

Wnioski: Eksenatyd był równie efektywny jak glargina w zakresie wyrównania gospodarki węglowodanowej w badanych grupach pacjentów z cukrzycą typu 2. Terapia eksenatydem skuteczniej obniżała glikemie poposiłkowe, zaś insulinoterapia zapewniała niższe glikemie na czczo. Przewagą leczenia eksenatydem była redukcja masy ciała oraz mniej epizodów hipoglikemii, jednak przy większej częstości objawów ubocznych ze strony przewodu pokarmowego. (Endokrynol Pol 2013; 64 (5): 375-382)

Słowa kluczowe: cukrzyca typu 2, agonista GLP-1, eksenatyd, insulina glargina

This study was sponsored by Eli Lilly and Company and Amylin Pharmaceuticals LLC. 


\section{Introduction}

Type 2 diabetes mellitus (T2DM) is a chronic, progressive disease, comprising one of the biggest unsolved problems of healthcare systems worldwide. Its progressive vascular complications, associated with an acceleration of atherosclerosis, are the main cause of the increased mortality of patients with T2DM [1-3]. Multifactorial therapeutic approaches play a vital role in preventing and blocking the macro- and microvascular diabetic complications. A more individualised therapeutic approach is often needed, using drugs with different mechanisms of action depending on the individual stage of diabetes [4].

It has been suggested that incretin hormones are an essential component of normal glucose homeostasis; they enhance glucose-dependent insulin secretion after meals $[5,6]$. The incretins, of which glucagon-like-peptide-1 (GLP-1) and glucose-dependent insulinotropic polypeptide (GIP) appear the most important in humans, are released from the intestines following food intake. The incretin effect describes the observation that oral glucose induces a greater insulin response compared to an equivalent intravenous challenge. The incretin response accounts for approximately $70 \%$ of the total insulin secreted following the administration of oral glucose [7]. Their mechanism of action is to increase insulin secretion, decrease glucagon release, reduce food intake, and slow gastric emptying, which makes GLP-1 based therapies appropriate for treatment of T2DM. They have been associated with improvement in postprandial and, to a lesser extent, fasting glucose levels. In addition, they have been associated with weight loss and may help to preserve $\beta$-cell function, both major problems in T2DM patients [8-11]. The outcomes of initial clinical trials with GLP-1 analogues or GLP-1 receptor activation as well as with inhibitors of dipeptidyl peptidase-4, the enzyme responsible for proteolysis of incretins, in T2DM patients were very promising [12-14]. In recent years, incretin-based therapy has attracted interest as a novel therapeutic alternative for patients with T2DM $[15,16]$.

To date, no clinical data has been reported for exenatide twice daily (bis in die, BID) treatment in patients from Poland. Therefore, we explored the safety and efficacy of exenatide BID $v$. the longacting insulin analogue glargine in a cohort of Polish patients participating in the global clinical trial reported by Heine et al. [17]. This randomised, multicentre, controlled, open-label trial compared exenatide BID $v$. insulin glargine in patients with T2DM sub-optimally controlled with metformin and a sulfonylurea.

\section{Material and methods}

\section{Data source and overall study protocol}

Data from a 26-week, multicentre, comparator-controlled, open-label, randomised, two-arm clinical trial was used for this analysis [17]. Following a four-week screening period, patients with T2DM sub-optimally controlled with metformin and a sulfonylurea were randomly assigned at baseline (1:1) to one of two injectable medications: exenatide BID (initial dose $5 \mu \mathrm{g}$ BID for four weeks, subsequently increased to $10 \mu \mathrm{g}$ BID; subcutaneously injected 15 minutes before morning and evening meals); or insulin glargine (injected subcutaneously once daily at bedtime, initial dose 10 IU per day). A fixed-dose algorithm was used to adjust the insulin glargine dose [17]. Patients self-titrated the dose in 2-IU increments every three days based on fasting blood glucose concentrations to achieve a target concentration of $<5.6 \mathrm{mmol} / \mathrm{L}(<100 \mathrm{mg} /$ $/ \mathrm{dL}$ ). The study was conducted in accordance with the principles described in the Declaration of Helsinki. All study participants gave informed written consent before participation. The overall clinical study protocol was approved by the Ethics Committees within each country; for Poland, this was the Ethical Review Board of the Medical University of Lublin.

The primary objective of the overall study was to test the hypothesis that glycaemic control, as measured by change in $\mathrm{HbA1c}$, achieved with exenatide BID is noninferior to that of insulin glargine. A further description of the study design has been published elsewhere [17].

\section{Study population}

For the overall trial, 551 patients had been randomised at 82 sites in 13 countries [17]. Of these, 80 patients, 40 in each treatment group, had been enrolled in Poland between June 2003 and April 2004. Table I summarises the main inclusion and exclusion criteria.

\section{Assessments}

$\mathrm{HbA}_{1 \mathrm{c}}$ was measured at screening, randomisation (baseline, week 0), and at Weeks 12 and 26. Blood chemistries were assessed at screening and at Weeks 12 and 26. A central laboratory performed all $\mathrm{HbA}_{1 \mathrm{c}}$ measurements, fasting serum glucose (FSG), and other laboratory tests. Seven-point, self-monitored blood glucose (SMBG) profiles were performed at screening and at Weeks 4 , $8,12,18$, and 26. Measurements were taken before the three main meals, two hours after the start of each meal, and during the night (3:00 a.m.).

Adverse events (AEs) were assessed at each visit. Symptomatic hypoglycaemia was defined as a blood glucose measurement below $3.4 \mathrm{mmol} / \mathrm{L}(<60 \mathrm{mg} / \mathrm{dL})$ or hypoglycaemia accompanied by typical clinical symp- 
Table I. Summary of main inclusion and exclusion criteria

Tabela I. Kryteria wtączenia i wytączenia

\section{Inclusion criteria}

Type 2 diabetes (WHO classification)

30-75 years of age, inclusive

Stable, optimal doses of metformin and SU for at least three months prior to screening

$\mathrm{HbA}_{1 \mathrm{c}}$ ranging from $7.0 \%$ to $10.0 \%$ at the time of screening

Body mass index ranging from $25 \mathrm{~kg} / \mathrm{m}^{2}$ to $45 \mathrm{~kg} / \mathrm{m}^{2}$

A history of stable body weight $(\leq 10 \%$ variation for $\geq 3$ months before screening)

\section{Exclusion criteria}

Participation in an interventional medical, surgical, or pharmaceutical study within 30 days before screening

More than three episodes of severe hypoglycaemia within six months before screening

Therapy for a malignant disease other than basal-cell or squamous-cell skin cancer

Cardiac disease that was class III or IV according to the New York Heart Association criteria

Serum creatinine concentration $>135 \mu \mathrm{mol} / \mathrm{L}$ (> $1.5 \mathrm{mg} / \mathrm{dL}$ ) for men or greater than $110 \mu \mathrm{mol} / \mathrm{L}$ ( $>1.2 \mathrm{mg} / \mathrm{dL}$ ) for women; or obvious clinical signs or symptoms of liver disease

Long-term ( $>2$ weeks) systemic glucocorticoid therapy or such therapy within two weeks immediately before screening

Using any prescription drug to promote weight loss within three months before screening

Treatment for $>2$ consecutive weeks with insulin within three months before screening, with thiazolidinediones within four months before screening, with alpha-glucosidase inhibitors within three months before screening, or with meglitinides within three months before screening

SU — sulfonylurea; WHO — World Health Organisation

toms. Severe hypoglycaemia was defined as an episode with symptoms consistent with hypoglycaemia in which the patient required the assistance of another person and which was associated with either a blood glucose concentration $<2.8 \mathrm{mmol} / \mathrm{L}(50 \mathrm{mg} / \mathrm{dL}$ ) or prompt recovery after oral carbohydrate, glucagon, or intravenous glucose.

\section{Statistical analysis}

All statistical analyses were done post-hoc on the subgroup of Polish patients who participated in the international clinical trial. Baseline characteristics, dose information, and AE data were analysed descriptively; means and standard deviations (SD) are presented for continuous variables. To explore the changes from baseline in $\mathrm{HbA}_{1 c^{\prime}}$ an exploratory analysis of covariance (ANCOVA) model was performed, with treatment and baseline $\mathrm{HbA} 1 \mathrm{c}$ as covariates, applying the last-observation-carried-forward (LOCF) approach. Results were presented as least-square (LS) means and standard error of the mean (SEM) for each group; and the corresponding $95 \%$ confidence interval (CI) for the treatment group difference was reported. Similar exploratory models were calculated for other continuous variables including body weight and hypoglycaemia rate. Self-monitoring blood glucose profiles were explored with the same analytical approach used for HbA1c. To explore categorical data, Fisher's exact tests were calculated as appropriate. However, no confirmatory conclusions can be drawn.
All results were presented for the intention-to-treat (ITT) population. The ITT population included all patients who took at least one dose of study drug and had at least one post-baseline measurement of the respective dependant variable. All calculations and analyses were performed using SAS software (SAS Institute, Inc., Cary, NC, USA).

\section{Results}

\section{Patient characteristics}

Of 551 patients randomised for the overall trial, 80 patients (14.5\% , 40 per treatment group) had been enrolled in Poland and are reported here. Of these, 76 patients completed the study; three patients were withdrawn due to protocol violations (one patient in the exenatide BID group, two patients in the insulin glargine group), and one patient was withdrawn in the exenatide BID group based on patient decision. No patient discontinued due to AEs.

Patient characteristics at baseline are presented in Table II; there were no notable differences between treatment groups. Patient age ranged between 41 and 75 years, and $56 \%$ were female.

In the Polish patient population, the mean final insulin glargine dose at week 26 was $16.6 \mathrm{U}$ (median 14, range 10-34 IU/day). Also the majority of exenatide patients in the Polish subset ( $\mathrm{n}=30$ of 38 at Week 26) achieved the target dose of $20 \mu \mathrm{g} / \mathrm{d}$. 
Table II. Baseline characteristics of the study population Tabela II. Charakterystyka badanej populacji

\begin{tabular}{lcc}
\hline Characteristic & $\begin{array}{c}\text { Exenatide } \\
\text { BID } \\
\mathbf{N}=\mathbf{4 0}\end{array}$ & $\begin{array}{c}\text { Insulin } \\
\text { glargine } \\
\mathbf{N}=\mathbf{4 0}\end{array}$ \\
\hline Age (years) & $60 \pm 9$ & $60 \pm 9$ \\
\hline Sex, female/male $(\mathrm{n})$ & $24 / 16$ & $21 / 19$ \\
\hline Weight $[\mathrm{kg}]$ & $84.6 \pm 15.86$ & $86.7 \pm 17.47$ \\
\hline BMl $\left[\mathrm{kg} / \mathrm{m}^{2}\right]$ & $32.0 \pm 4.41$ & $32.1 \pm 5.23$ \\
\hline Fasting serum glucose $[\mathrm{mmol} / \mathrm{L}]$ & $9.7 \pm 0.35$ & $9.5 \pm 0.35$ \\
\hline HbA1c $(\%)$ & $7.9 \pm 0.86$ & $7.8 \pm 1.02$ \\
\hline Duration of diabetes (years) & $9.15 \pm 4.87$ & $7.65 \pm 5.41$ \\
\hline Systolic blood pressure $[\mathrm{mm} \mathrm{Hg}]$ & $138 \pm 14.2$ & $143 \pm 15.7$ \\
\hline Diastolic blood pressure $[\mathrm{mm} \mathrm{Hg}]$ & $80 \pm 7.2$ & $84 \pm 5.8$ \\
\hline
\end{tabular}

Data is for the intent-to-treat population. Values for continuous variables are expressed as means \pm SD. BID — twice daily; BMI — body mass index; SD standard deviation

\section{Glycaemic control: $\mathrm{Hb} A_{1 c}$ and FSG}

Least-square mean $\mathrm{HbA}_{1 \mathrm{c}}$ decreased from baseline to Week 26 in both treatment groups (Fig. 1). In the exenatide BID group, LS mean (SEM) changes in $\mathrm{HbA}_{1 \mathrm{c}}$ were $-0.72 \%(0.12)$ at Week 26 . In the insulin glargine group, the corresponding change was $-0.64 \%(0.12)$. This translated into an estimated treatment group difference of $-0.07 \%$ (LS mean group difference exenatide BID minus insulin glargine, based on exploratory ANCOVA: $-0.07 \%$ (0.17) [95\% CI: -0.41 to 0.26$])$.

At Week $26,42 \%$ of patients on exenatide and $38 \%$ of patients on insulin glargine had achieved the $\mathrm{HbA}_{1 \mathrm{c}}$ target of $\leq 7 \%$. Fasting serum glucose concentrations decreased in both treatment groups from baseline to Week 26. Least-square mean (SEM) FSG concentrations decreased by $-0.56(0.40) \mathrm{mmol} / \mathrm{L}$ in patients treated with exenatide BID and by $-1.43(0.39) \mathrm{mmol} / \mathrm{L}$ in patients treated with insulin glargine; starting from baseline concentrations of $9.67(0.35) \mathrm{mmol} / \mathrm{L}$ and $9.47(0.35) \mathrm{mmol} / \mathrm{L}$, respectively. For the change in FSG, the LS mean treatment group difference $[95 \% \mathrm{CI}] \mathrm{de}-$ rived from the exploratory ANCOVA model (exenatide minus insulin glargine) was 0.87 [ -0.24 to 1.98$] \mathrm{mmol} / \mathrm{L}$.

\section{Body weight}

Patients on exenatide BID progressively lost body weight, while patients on insulin glargine gained weight (Fig. 2). Baseline mean (SD) body weights were 84.6 (15.86) kg and 86.7 (17.47) $\mathrm{kg}$ in the exenatide BID and the insulin glargine group, respectively. LS mean (SEM) weight decreased by $-1.9(0.48) \mathrm{kg}$ on exenatide BID compared to a weight gain of $1.6(0.48) \mathrm{kg}$ on insulin glargine. At Week 26, the treatment group difference had reached

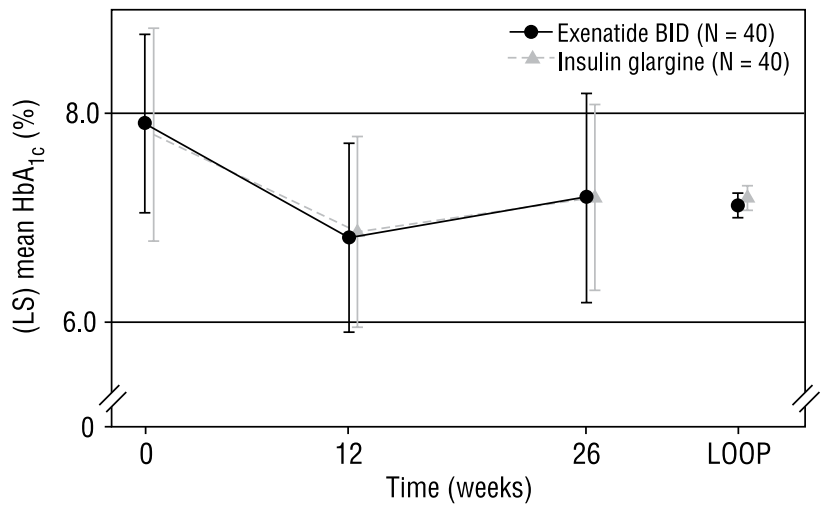

Figure 1. (LS) Mean $\mathrm{Hb}_{1 c}$ (\%) at each visit and at end-point, intent-to-treat population. Presented are mean and standard deviation for the values at each visit $(0,12$, and 26 weeks); LS mean and standard error for the value at end-point (LOCF, from exploratory analysis of covariance analysis). BID — twice daily; LOCF - last observations carried forward; LS - least-square

Rycina 1. Zmiany $H b A_{1 C}$ podczas poszczególnych wizyt w obu grupach badanych

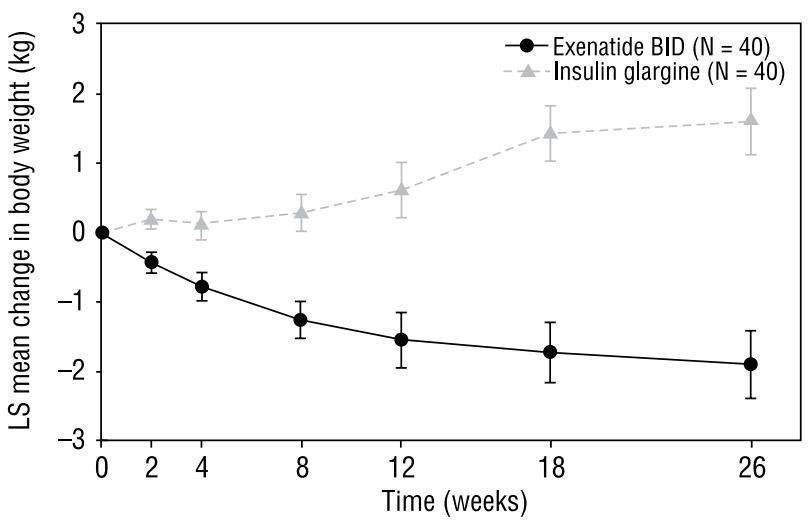

Figure 2. LS mean change of body weight at each visit, intent-totreat population. Error bars indicate standard error of the mean. BID - twice daily; LS - least-square; wks - weeks

Rycina 2. Zmiany masy ciała podczas poszczególnych wizyt w obu grupach badanych

$-3.5 \mathrm{~kg}$ (LS mean group difference exenatide BID minus insulin glargine, based on exploratory ANCOVA: -3.5 (0.68) $\mathrm{kg}$ [95\% CI: -4.9 to $-2.2 \mathrm{~kg}], \mathrm{p}<0.001)$.

\section{$S M B G$ profiles}

Average SMBG profiles at baseline and Week 26 are shown in Figure 3. In the exenatide BID group, the primary change was in postprandial glucose excursions, whereas in the insulin glargine group, the primary change was a reduction in fasting glucose concentrations. In the exploratory ANCOVA analysis, LS mean (SEM) glucose excursions associated with exenatide BID decreased by $2.3(0.28) \mathrm{mmol} / \mathrm{L}$ after breakfast and by $1.6(0.24) \mathrm{mmol} / \mathrm{L}$ after dinner, compared to $0.3(0.29)$ 
A

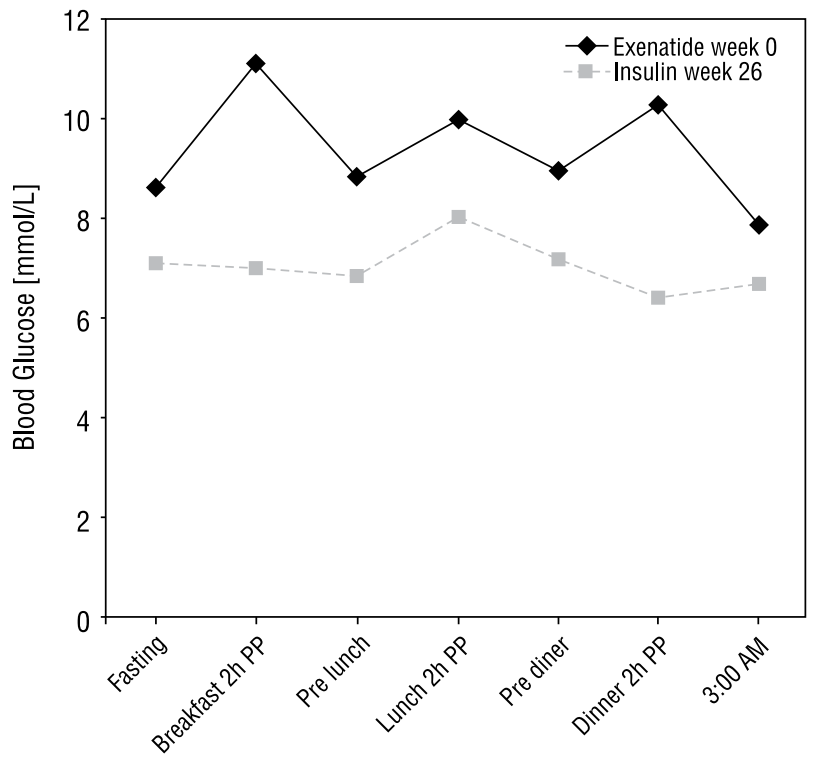

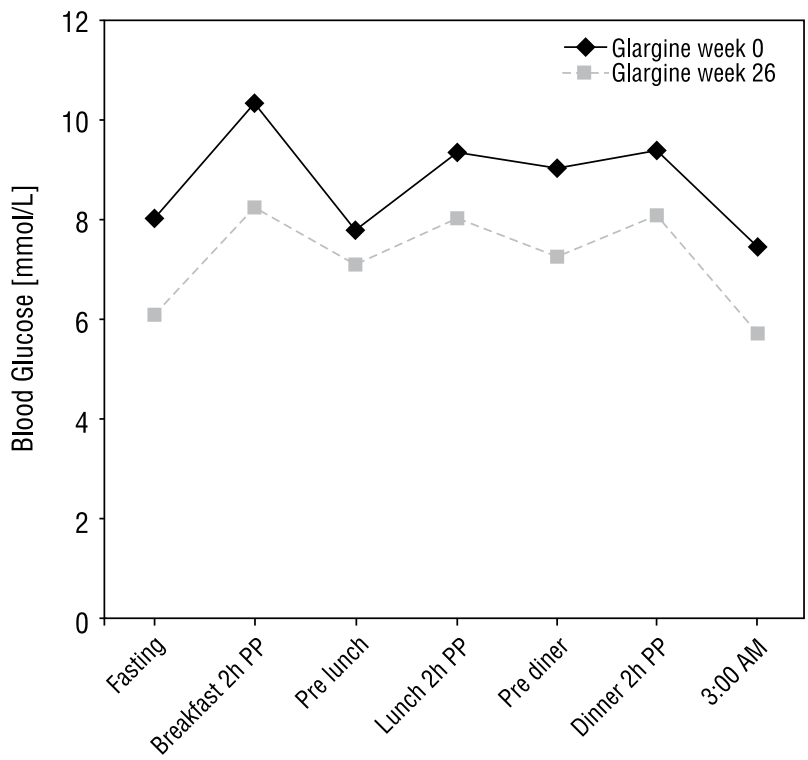

Figure 3. Mean seven-point SMBG profiles at baseline and Week 26 in both treatment groups, intent-to-treat population. PP — postprandial; SMBG — self-monitoring blood glucose

Rycina 3. Siedmiopunktowy profil glikemii na początku badania i w 26. tygodniu, w grupach badanych

$\mathrm{mmol} / \mathrm{L}$ and $0.2(0.24) \mathrm{mmol} / \mathrm{L}$ with insulin glargine (exploratory $\mathrm{p}<0.001$ for both meals). The responses after lunch in both treatment groups were similar.

\section{Adverse events}

Treatment-emergent AEs that occurred in $\geq 5 \%$ of patients are shown in Table III. Gastrointestinal events were more common in the exenatide BID group than in the insulin glargine group. No patients withdrew because of nausea or other gastrointestinal symptoms. All other AEs occurred only once.

\section{Hypoglycaemia}

Overall, 17 patients $(42.5 \%)$ in the exenatide BID group and 14 patients $(35.0 \%)$ in the insulin glargine group reported at least one hypoglycaemic episode. Hypoglycaemia rates were low in both groups with 0.1 events/ patient/30 days (Table IV). Few patients in the exenatide BID group experienced nocturnal hypoglycaemic events - three patients reported one episode each, compared to seven patients reporting 24 episodes in the insulin glargine group, although this was not statistically significantly different.

\section{Discussion}

A post-hoc pooled analysis found that both treatments, patients treated with exenatide BID and starter insulins, experienced improvement in fasting glucose concentrations. Although changes in LS mean fasting
Table III. Adverse events reported in $\geq 5 \%$ of patients

Tabela III. Zdarzenia niepożądane występujące $u \geq 5 \%$ pacjentów

\begin{tabular}{lcccc}
\hline & \multicolumn{2}{c}{$\begin{array}{c}\text { Exenatide BID } \\
\text { (N = 40) }\end{array}$} & \multicolumn{2}{c}{$\begin{array}{c}\text { Insulin glargine } \\
\text { (N = 40) }\end{array}$} \\
\hline Preferred term & $\mathrm{n}(\%)$ & $\mathrm{n}$ events & $\mathrm{n}(\%)$ & $\mathrm{n}$ events \\
\hline Nausea & $17(43 \%)$ & 22 & $1(3 \%)$ & 1 \\
\hline Headache & $4(10 \%)$ & 8 & $2(5 \%)$ & 2 \\
\hline Vomiting & $4(10 \%)$ & 5 & $0(0 \%)$ & 0 \\
\hline Nasopharyngitis & $4(10 \%)$ & 4 & $2(5 \%)$ & 2 \\
\hline Upper abdominal pain & $3(8 \%)$ & 3 & $0(0 \%)$ & 0 \\
\hline Hypertension & $2(5 \%)$ & 2 & $0(0 \%)$ & 0 \\
\hline $\begin{array}{l}\text { Respiratory tract } \\
\text { infection }\end{array}$ & $2(5 \%)$ & 2 & $0(0 \%)$ & 0 \\
\hline BID - twice daily & & & & \\
\hline
\end{tabular}

glucose concentrations from baseline at 26 weeks in the insulin treatment group were statistically different from the exenatide BID treatment group in favour of the insulin group, these differences were not observed in the subgroup treated for one year. At 52 weeks, the LS mean fasting glucose concentrations were $-1.9 \mathrm{mmol} / \mathrm{L}$ and $-2.0 \mathrm{mmol} / \mathrm{L}$ for patients treated with insulin and exenatide BID, respectively [18].

Based on SMBG profiles, patients treated with exenatide BID had smaller postprandial glucose excursions, especially after morning and evening meals, 
Table IV. Hypoglycaemia rates (events/patient/30 days)

Tabela IV. Częstość występowania hipoglikemii (epizod hipoglikemii/pacjent/30 dni)

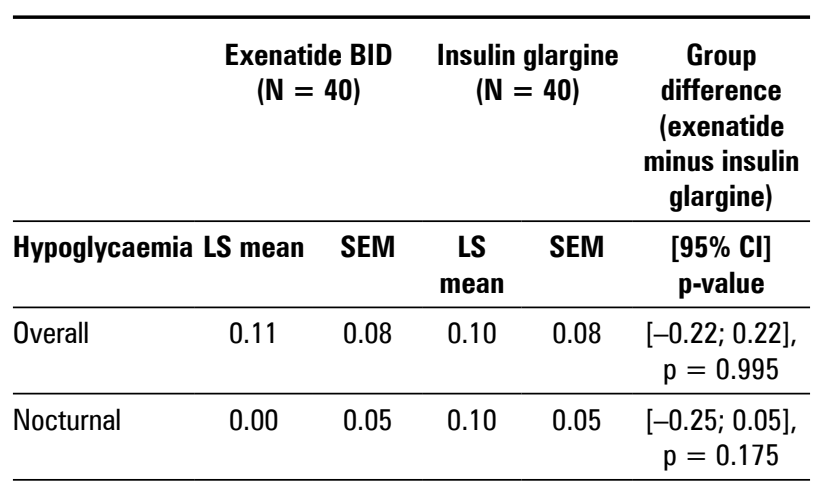

$\mathrm{CI}$ — confidence interval; LS — Least-square, SEM — standard error of the mean

whereas insulin glargine appeared to predominantly affect fasting glucose concentrations. This pattern is consistent with the timing of dosing and exenatide's mode of action.

According to an analysis of epidemiological studies by Ceriello et al., postprandial hyperglycaemia is associated with a higher risk of cardiovascular disease and an increase in overall mortality [19]. Glucagonlike-peptide-1 receptor agonists and other therapies shown to be effective in reducing postprandial glucose excursions may therefore potentially improve this cardiovascular risk factor [17, 19-24].

One of the main factors that differentiates exenatide BID from insulin - reduction in body weight - was also observed in this country-specific patient cohort from Poland; mean weight decreased by -1.9 $\mathrm{kg}$ in the exenatide BID group and increased by $1.6 \mathrm{~kg}$ in the insulin glargine group. Weight control is one of the important considerations in the treatment of patients with T2DM, according to the American Diabetes Association and the Polish Diabetes Association $[24,25]$. Overweight and obesity are independent cardiovascular risk factors, and body weight reduction should be an integral component of treatment [26, 27]. The majority of oral glucose-lowering drugs used in T2DM, as well as insulin, result in weight gain or are at most weight-neutral [28]. Glucagon-like-peptide-1 receptor agonists have consistently been demonstrated to have unique effects on reducing body weight [20, 27-30]. In the UK Prospective Diabetes Study, the significant advantage of metformin over other oral antidiabetes medications in overweight and obese patients has been clearly shown [31]. Exenatide has been shown to reduce body weight in animals as well as in humans [32-35]. Exenatide reduced food intake in rodents following either central or peripheral administration. Exenatide has been shown to inhibit the kinetics and secretory functions of the gastrointestinal tract, especially gastric emptying, which may result in a reduction of caloric intake and a progressive body weight reduction in rodents [34, 35] and humans [36]. This potential anorectic effect of exenatide and GLP-1 is assumed to be caused by an activation of peripheral visceral nerve fibre endings located in the stomach wall, regulating the rate of stomach emptying [37, 38]. But in addition, GLP-1 also acts centrally on the hypothalamic satiety centre, particularly on neurons of the arcuate nucleus in rats [39]. Currently, there is disagreement as to whether the central effect is or is not independent of the activation of peripheral visceral nerve fibres' endings in the stomach wall [38, 40]. Consistent with the weight reduction observed in animal studies, exenatide BID treatment among patients with T2DM has been associated with a delay in gastric emptying [40].

Use of exenatide BID may be more convenient for patients than treatment with insulin which requires more attention and trained personnel [41]. The difficulty of monitoring and changing the doses of insulin is eliminated with the use of exenatide BID which does not require dose titration beyond the first month of treatment and the need for routine SMBG surveillance is reduced in those patients who do not receive concomitant sulfonylurea [42].

Hypoglycaemia is a common and typical AE of drugs stimulating insulin secretion, such as sulfonylureas. The incidence of hypoglycaemic events increases according to the intensity of therapy administered to achieve adequate glycaemic control [43]. In this Polish cohort, hypoglycaemia rates were low (0.1 events/patient/30 days) in both groups; nocturnal hypoglycaemia was reported for three patients on exenatide BID $v$. seven patients on insulin glargine (three v. 24 episodes). In previous studies, hypoglycaemic episodes (usually mild) were noted primarily when exenatide was given in combination with a sulfonylurea, whereas they were less common when exenatide was combined with metformin [44]. This finding may be connected to the mode of action of these drugs. The potential insulinotropic effect of exenatide is glucose-dependent [45]. In contrast, sulfonylureas increase insulin secretion independently of glucose concentration, thereby resulting in a higher potential incidence of hypoglycaemia [44]. The possible interaction between molecular actions of GLP-1 and glucose-lowering drugs such as sulfonylureas should be emphasised. Sulfonylureas can reduce the interaction between GLP-1 and glucose concentration, mainly by blocking of the $\mathrm{K}$ channel of adenosine triphosphate in b-cells, resulting in a persistent stimulation of insulin secretion [45-47]. 
The data is not entirely up-to-date (2004/2005) and these factors are potential limitations. The low patient number precludes any confirmatory conclusions.

\section{Conclusions}

This exploratory subgroup analysis confirms that findings from the global study apply to patients treated with exenatide BID and glargine in Poland, showing that exenatide BID was as effective as insulin glargine. For this cohort of patients with T2DM inadequately controlled by metformin and sulfonylurea combination treatment, the data suggests that the changes in HbA1c were certainly similar, but decreases in fasting glucose were greater in the insulin glargine group and postprandial excursions were fewer in patients treated with exenatide BID. As previously seen in several large international trials, exenatide BID was associated with body weight reduction, a low incidence of nocturnal hypoglycaemia, but frequent occurrence of mild to moderate gastrointestinal events.

\section{Acknowledgments}

The authors express their appreciation to the following Polish investigators who participated in this study: K. Cypryk (Lodz), T. Kasperska-Czyzyk (Warsaw), A. Kozlowski (Mielec), K. Janik (Czestochowa), E. Jarosz-Skokowska (Lublin), K. Markiewicz (Warsaw), M. Polaszewska-Muszynska (Bydgoszcz), E. Semetkowska-Jurkiewicz (Gdansk), A. Stankiewicz (Krakow).

\section{References}

1. Weyer C, Bogardus C, Mott DM et al. The natural history of insulin secretory dysfunction and insulin resistance in the pathogenesis of type 2 diabetes mellitus. J Clin Invest 1999; 104: 787-794.

2. Butler AE, Janson J, Bonner-Weir S et al. Beta-cell deficit and increased beta-cell apoptosis in humans with type 2 diabetes. Diabetes 2003; 52 : 102-10.

3. Yusuf S, Hawken S, Ounpuu S et al. Effect of potentially modifiable risk factors associated with myocardial infarction in 52 countries (the INTERHEART study): case-control study. Lancet 2004; 364: 937-952.

4. Inzucchi SE, Bergenstal RM, Buse JB et al. Management of hyperglycaemia in type 2 diabetes: a patient-centered approach. Position statement of the American Diabetes Association (ADA) and the European Association for the Study of Diabetes (EASD). Diabetologia 2012; 55: 1577-1596.

5. Creutzfeldt W. Entero-insular axis and diabetes mellitus. Horm Metab Res Suppl 1992; 26: 13-18.

6. Holst JJ, Gromada J. Role of incretin hormones in the regulation of insulin secretion in diabetic and nondiabetic humans. Am J Physiol Endocrinol Metab 2004; 287: E199-206.

7. Nauck MA, Homberger E, Siegel EG et al. Incretin effects of increasing glucose loads in man calculated from venous insulin and C-peptide response. J Clin Endocrinol Metab 1989; 63: 492-498.

8. Knop FK, Vilsbøll T, Højberg PV et al. Reduced incretin effect in type 2 diabetes: cause or consequence of the diabetic state? Diabetes 2007 56: 1951-1959.

9. Matuszek B, Lenart-Lipińska M, Nowakowski A. Incretin hormones in the treatment of type 2 diabetes. Part II. Incretins - new possibilities for pharmacotherapy of type 2 diabetes. Endokrynol Pol 2008; 59: 322-329.

10. Toft-Nielsen MB, Damholt MB, Madsbad S et al. Determinants of the impaired secretion of glucagon-like peptide- 1 in type 2 diabetes patients. J Clin Endocrinol Metab 2001; 86: 3717-3723.
11. Russell-Jones D, Gough S. Recent advances in incretin-based therapies. Clin Endocrinol (Oxf) 2012; 77: 489-499.

12. Nauck MA, Sauerwald A, Ritzel R et al. Influence of glucagon-like peptide 1 on fasting glycemia in type 2 diabetic patients treated with insulin after sulfonylurea secondary failure. Diabetes Care 1998; 21: 1925-1931.

13. Zander M, Madsbad S, Madsen JL et al. Effect of 6-week course of glucagon-like peptide 1 on glycaemic control, insulin sensitivity, and beta-cell function in type 2 diabetes: a parallel-group study. Lancet 2002; 359: 824-830.

14. Hinnen D, Nielsen LL, Waninger A et al. Incretin mimetics and DPP-IV inhibitors: new paradigms for the treatment of type 2 diabetes. J Am Board Fam Med 2006; 19: 612-620.

15. Martin JH, Deacon CF, Gorrell MD et al. Incretin - based therapiesreview of the physiology, pharmacology and emerging clinical experience. Intern Med J 2011; 41: 299-307.

16. Ahrén B. GLP-1 for type 2 diabetes. Exp Cell Res 2011; 317: 1239-1245.

17. Heine RJ, Van Gaal LF, Johns D et al. Exenatide versus insulin glargine in patients with suboptimally controlled type 2 diabetes: a randomized trial. Ann Intern Med 2005; 143: 559-569.

18. Blevins T, Han J, Nicewarner D et al. Exenatide is non-inferior to insulin in reducing HbA1c: an integrated analysis of 1423 patients with type 2 diabetes. Postgrad Med 2010; 122: 118-128.

19. Ceriello A. Postprandial hyperglycemia and diabetes complications: is it time to treat? Diabetes 2005; 54: 1-7.

20. Klonoff DC, Buse JB, Nielsen LL et al. Exenatide effects on diabetes, obesity, cardiovascular risk factors and hepatic biomarkers in patients with type 2 diabetes treated for at least 3 years. Curr Med Res Opin 2008; 24: 275-286.

21. Davis SN, Johns D, Maggs D et al. Exploring the substitution of exenatide for insulin in patients with type 2 diabetes treated with insulin in combination with oral antidiabetes agents. Diabetes Care 2007; 30: 2767-2772.

22. Barnett AH, Burger J, Johns D et al. Tolerability and efficacy of exenatide and titrated insulin glargine in adult patients with type 2 diabetes previously uncontrolled with metformin or a sulfonylurea: a multinational randomized, open-label, two-period, crossover noninferiority trial. Clin Ther 2007; 29: 2333-2348.

23. Nauck MA, Duran S, Kim D et al. A comparison of twice-daily exenatide and biphasic insulin aspart in patients with type 2 diabetes who were suboptimally controlled with sulfonylurea and metformin: a noninferiority study. Diabetologia 2006; 50: 259-267.

24. Klein S, Sheard NF, Pi-Sunyer X et al. Weight management through lifestyle modification for the prevention and management of type 2 diabetes: rationale and strategies: a statement of the American Diabetes Association, the North American Association for the Study of Obesity, and the American Society for Clinical Nutrition. Diabetes Care 2004; 27: 2067-2073.

25. Polskie Towarzystwo Diabetologiczne. Zalecenia kliniczne dotyczące postępowania u chorych na cukrzycę, 2012. Diabetologia Kliniczna 2012; 1 (Suppl. A).

26. Peters AL. Patient and treatment perspectives: Revisiting the link between type 2 diabetes, weight gain, and cardiovascular risk. Cleve Clin J Med 2009; 76(Suppl. 5): S20-27.

27. Davidson $\mathrm{MH}$. Cardiovascular effects of glucagonlike peptide- 1 agonists. Am J Cardiol 2011; 108 (3 Suppl.): 33B-41B

28. Jendle J, Nauck MA, Matthews DR et al. Weight loss with liraglutide, a once-daily human glucagon-like peptide- 1 analogue for type 2 diabetes treatment as monotherapy or added to metformin, is primarily as a result of a reduction in fat tissue. Diabetes Obes Metab 2009; 11: 1163-72.

29. Bunck MC, Diamant M, Eliasson B et al. Exenatide affects circulating cardiovascular risk biomarkers independently of changes in body composition. Diabetes Care 2010; 33: 1734-1737.

30. Nielsen LL, Okerson T, Holcombe J et al. Effects of exenatide on diabetes, obesity, cardiovascular risk factors, and hepatic biomarkers in patients with type 2 diabetes. J Diabetes Sci Technol 2008; 2: 255-260.

31. UK Prospective Diabetes Study (UKPDS) Group. Effect of intensive blood-glucose control with metformin on complications in overweight patients with type 2 diabetes (UKPDS 34). Lancet 1998; 352: 854-865.

32. Kendall DM, Kim D, Poon T et al. Improvement in cardiovascular risk factor accompanied sustained effects on glycaemia and weight reduction in patients with type 2 diabetes treated with exenatide for 82 weeks. Diabetes 2005; 54 (Suppl. 1): A4-A5.

33. Navarro M, Rodriguez de Fonseca F, Alvarez E et al. Colocalization of glucagon-like peptide-1 (GLP-1) receptors, glucose transporter GLUT-2 and glucokinase mRNAs in rat hypothalamic cells: evidence for a role of GLP-1 receptor agonists as an inhibitory signal for food and water intake. J Neurochem 1996; 67: 1982-1991.

34. Al-Barazanji KA, Arch JR, Buckingham RE et al. Central exendin-4 infusion reduced body weight without altering plasma leptin in $(\mathrm{fa} / \mathrm{fa})$ Zucker rats. Obes Res 2000; 8: 317-323.

35. Mack CM, Moore CX, Jodka CM et al. Antiobesity action of periphera exenatide (exendin-4) in rodents: effects on food intake, body weight, metabolic status and side-effect measures. Int J Obes (Lond) 2006; 30 1332-1340. 
36. Nauck MA Unraveling the science of incretin biology. Am J Med 2009; 122: S3-S10

37. Nagell CF, Wattergren A, Orskov C et al. Inhibitory effect of GLP-1 on gastric motililty persists effect vagal deafferentiation in pigs. Scand J Gastroenterolog 2006; 41: 667-672.

38. Talsania T, Anini Y, Siu S et al. Peripheral exendin- 4 and peptide 44 (3-36) synergistically reduce fodd intake through different mechanisms in mice. Endocrinology 2005; 146: 3748-3756.

39. D'Alessio DA, Sandoval DA, Seeley RJ. New ways in which GLP-1 can regulate glucose homeostasis. J Clin Invest 2005; 115: 3406-3408.

40. Linnebjerg H, Park S, Kothare PA et al. Effect of exenatide on gastric emptying and relationship to posprandial glycemia in type 2 diabetes. Regul Pept 2008; 151: 123-129.

41. Mojtahedzadeh M, Jafarieh A, Najafi A et al. Comparison of metformin and insulin in the control of hyperglycaemia in non-diabetic critically ill patients. Endokrynol Pol 2012; 63: 206-211.
42. Exenatide (Summary of Product Characteristics). Houten, The Netherlands: Eli Lilly Nederland BV; 2012.

43. Cryer PE, Davis SN, Shamoon H. Hypoglycemia in diabetes. Diabetes Care 2003; 26: 1902-1912.

44. Cvetković RS, Plosker GL. Exenatide: a review of its use in patients with type 2 diabetes mellitus (as an adjunct to metformin and/or a sulfonylurea). Drugs 2007; 67: 935-954.

45. Gentilella R, Bianchi C, Rossi A et al. Exenatide: a review from pharmacology to clinical practice. Diabetes Obes Metab 2009; 11 : 544-556.

46. Itz JL, Baker DE, Setter SM et al. Exenatide: an incretin mimetic for the treatment of type 2 diabetes mellitus. Clin Ther 2006; 28: 652-665.

47. Robles GI, Singh-Franco D. A review of exenatide as adjunctive therapy in patients with type 2 diabetes. Drug Des Devel Ther 2009; 3: 219-240. 